\title{
Bilateral Renal Adenocarcinoma Associated with Von Hippel Lindau Disease: A Case Report

\author{
O. Elhouadfi ${ }^{1^{*}}$, A. Saouli ${ }^{2}$, I. Zarda ${ }^{2}$, T.Karmouni ${ }^{2}$, K. El Khader ${ }^{2}$, A. Koutani ${ }^{2}$, A. Iben Attya Andaloussi ${ }^{2}$
}

${ }^{1}$ Urology Department of the Mohammed V Military Hospital, Rabat, Morocco

${ }^{2}$ Urology B Department of the CHU Ibn Sina, Mohamed V University, Rabat, Morocco

DOI: $\underline{10.36347 / \mathrm{sasjs} .2021 . \mathrm{v} 07 \mathrm{i} 04.015}$

| Received: 16.03.2021 | Accepted: 22.04.2021 | Published: 30.04.2021

*Corresponding author: Othmane El Houadfi

\section{Abstract}

Case Report

The von Hippel-Lindau (VHL) is an autosomal dominant disease predisposing to the development of various tumors (hemangioblastomas central nervous system and retina, endolymphatic sac tumors, clear cell cancer or renal cysts, pheochromocytoma, cysts or tumors pancreatic, epididymal cystadenoma).We report here a report case of a man aged 57 who present bilateral renal clear cell carcinoma. This patient underwent a bilateral tumorectomy three-month intervals between the two interventions. The postoperative evolution was favorable with a 24-month decline without local recurrence.

Keywords: Von-Hippel-Lindeau ; Adenorcarcinoma ;Kidney.

Copyright $\odot 2021$ The Author(s): This is an open-access article distributed under the terms of the Creative Commons Attribution 4.0 International License (CC BY-NC 4.0) which permits unrestricted use, distribution, and reproduction in any medium for non-commercial use provided the original author and source are credited.

\section{INTRODUCTION}

Von Hippel-Lindau (VHL) disease is an inherited disease predisposing to the development of richly vascularized benign and malignant tumors that is due to germline mutations in the VHL tumor suppressor gene. Major clinical manifestations include CNS and retinal hemangioblastomas, endolymphatic sac tumors, clear cell cancers and renal cysts, pheochromocytomas, cysts, and pancreatic endocrine tumors [1]. Oncogenetic consultation of one or more affected subjects and then of family members allows the detection and screening of mutations in the VHL gene and the identification of subjects predisposed to this disease. In this article we present the clinical case of a patient with bilateral RCC in the context of VHL disease.

Observation: This is a 57 year old patient with a family history of a brother who died of a renal tumor and his sister operated for a brain tumor, the patient accuses of isolated chronic bilateral low back pain. The clinical examination showed tenderness in both flanks.

Biologically, the renal function was normal. It was completely normalized after a small deterioration after the clamping of the 2 nd operation.

Radiologically, the abdominal CT scan showed two bilateral renal tumors in each kidney with cortical cysts. (Fig. 1A, 1B, 1C),

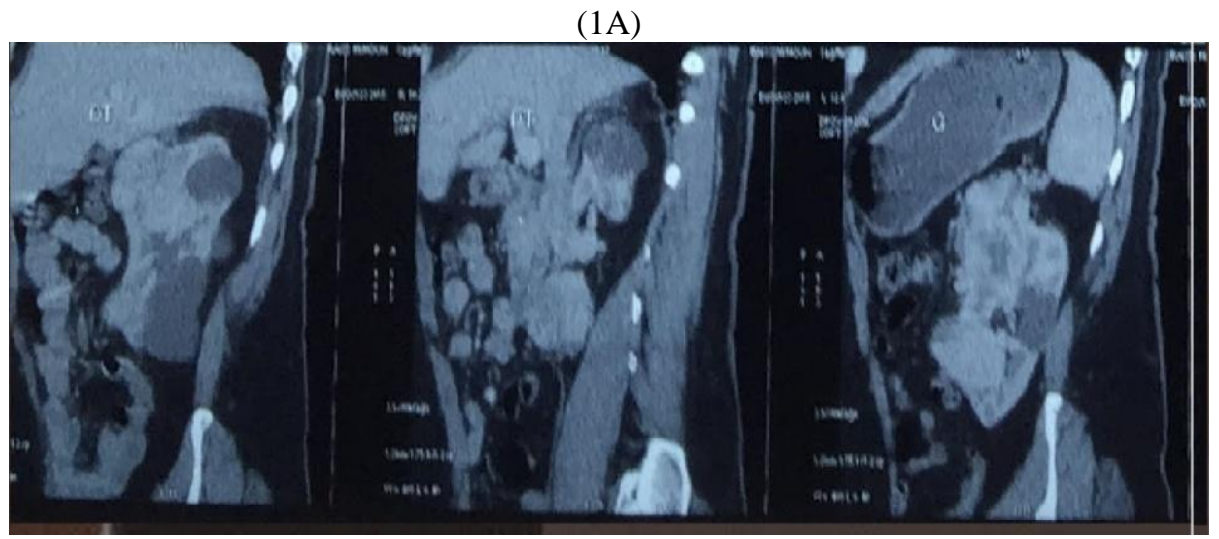




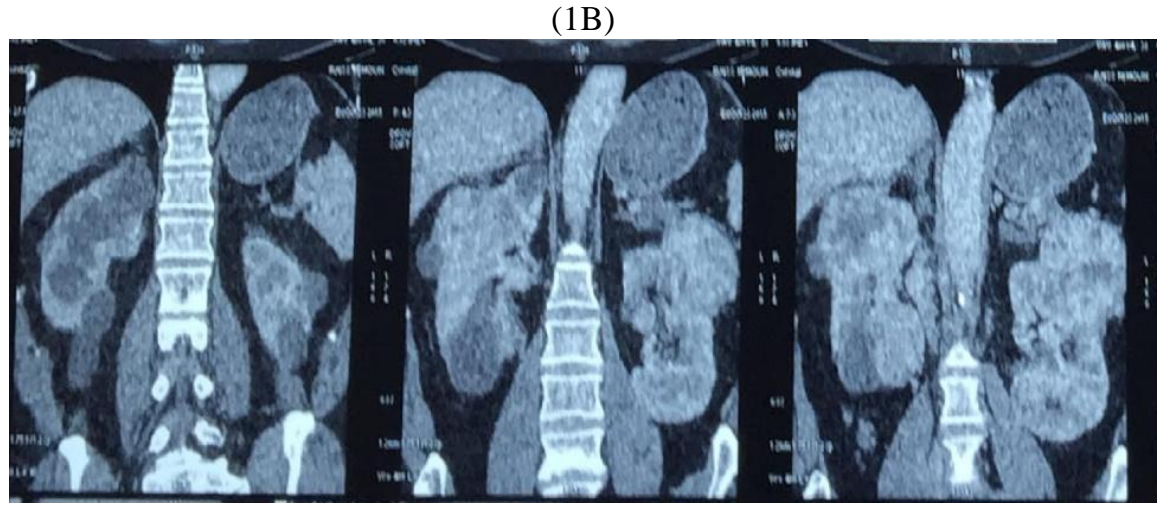

$(1 \mathrm{C})$

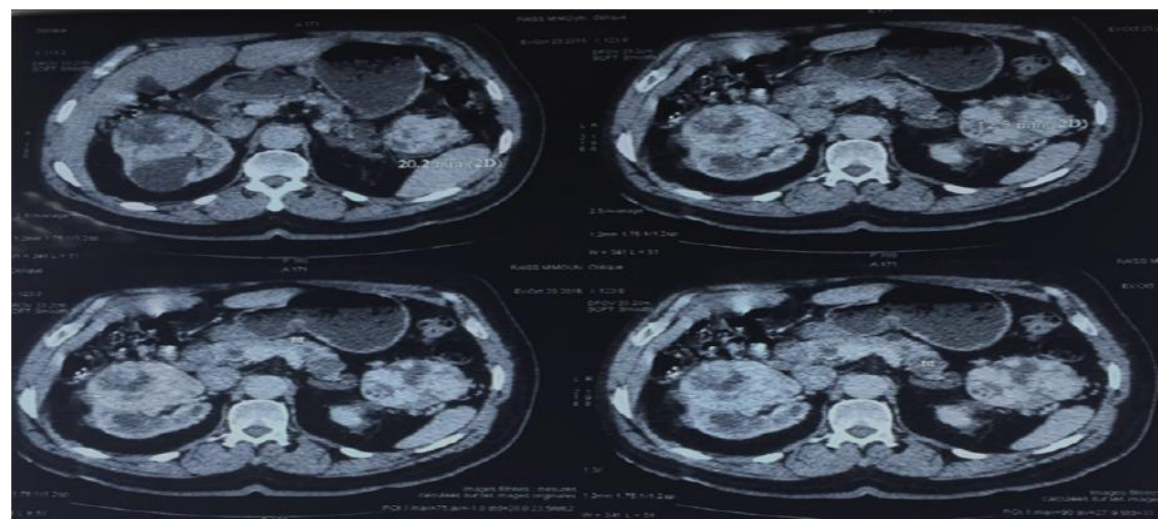

Fig-(1A, 1B, 1C): Sagittal (1A), Frontal (1B), and Axial (1C) Sections of Abdominal CT Scan with Contrast Injection (PDC) Showing a Bilateral, Multi-Lobulated Renal Tumor Process Enhancing Heterogeneously with Cortical Cysts

The diagnosis of VHL disease was evoked, we completed by a brain CT which was normal. Our patient was not tested for the VHL gene. The treatment consisted of a bilateral open tumorectomy with a threemonth interval between the two procedures.Histological examination of the surgical material led to a diagnosis of renal clear cell carcinoma. (Fig-2) (Fig-3) The postoperative follow-up was simple with a 12-month follow-up without recurrence.

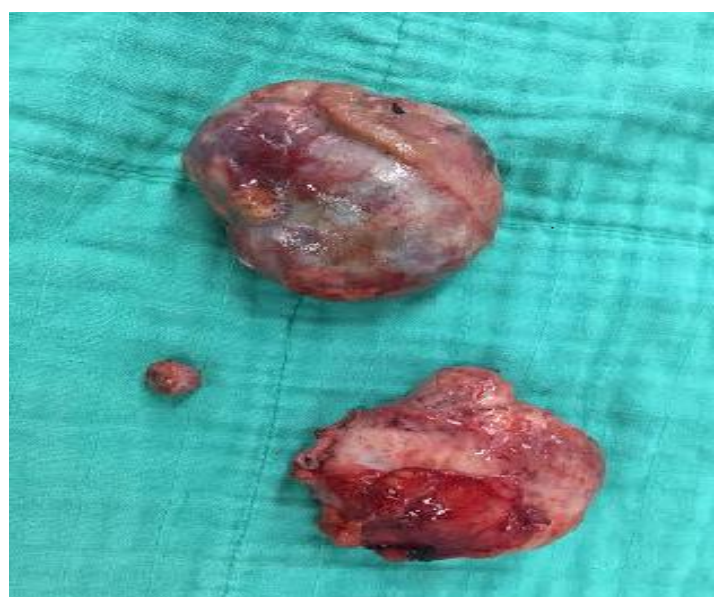

Fig-2: Macroscopic appearance of three nodules of the enucleo-resection of the left renal tumor well circumscribed by a thin capsule with a total weight of 260g:
- A small nodule of $1 \mathrm{~cm}$ of dirty grayish appearance with presence of areas of hemorrhagic remodeling and a Führmann grade of 1 .

- A medium nodule of $7 \times 5.5 \times 4 \mathrm{~cm}$ and a large nodule of $8 \times 6.5 \times 5.5 \mathrm{~cm}$, with a polychromatic appearance on section with orange-yellow areas, areas of haemorrhagic changes and a Führmann grade of 2 .

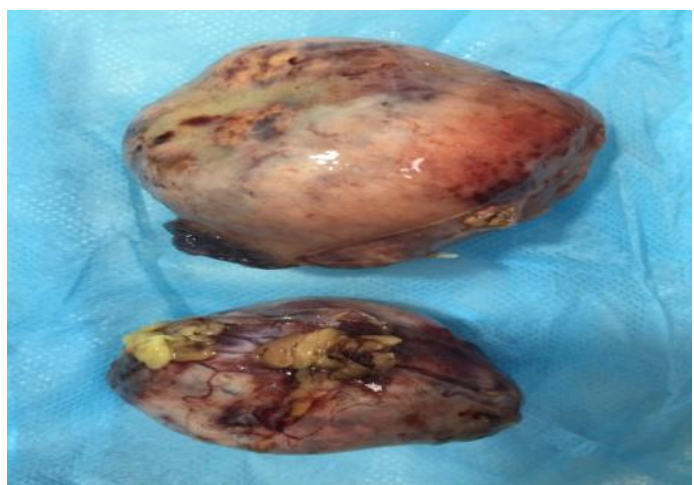

Fig-3: Macroscopic appearance of two tumor masses on the right side, one weighs $63 \mathrm{~g}$ and measures $7 \times 6 \times 4 \mathrm{~cm}$ and the other weighs $120 \mathrm{~g}$ and measures $8 \times 8 \times 4.5 \mathrm{~cm}$, they are surrounded by a fibrous capsule. On section, almost similar aspect, fleshy, sulphur yellow, and in places greyish, with haemorrhages, with a yellowish focus of necrosis in the center of the small mass and a focus of fibrosis in the large mass. 


\section{DISCUSSION}

VHL disease is a rare hereditary phacomatosis; its incidence fluctuates from $1 / 36000$ to $1 / 45500$ births. It is an autosomal dominant disease with high penetrance ( $95 \%$ at 60 years of age), for which a single gene is responsible: the VHL gene located on the short arm of chromosome 3 (3p25-p26) [2].It associates retinal and central nervous system hemangioblastomas (60-80\%), renal adenocarcinomas and cysts (30-60\%), pancreatic cysts and tumors (30-70\%), pheochromocytomas (10-20\%), endolymphatic sac tumors (2-11\%), epididymal cystadenomas (20-50\%) (Fig-4) [3].

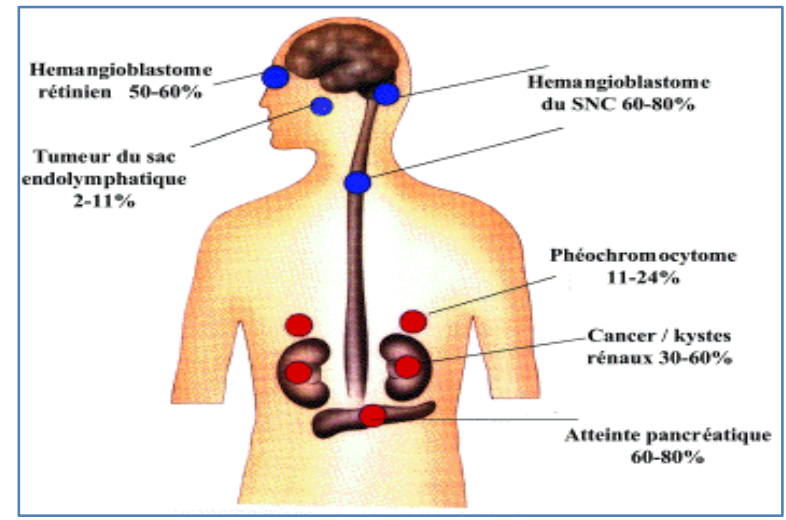

Fig-4

In adults, CRCC accounts for about $3 \%$ of all cancers and $85 \%$ of all primary renal malignancies [4], they are hereditary in about $5 \%$, VHL accounts for $75 \%$ of the hereditary forms [5]. The CRCC and cysts in VHL disease are characterized by multicentricity and bilateral localization in $>75 \%$ of patients $[6,7]$. The median age at presentation is 10-20 years earlier than the age indicated for sporadic renal disease [8]. CRCC and cysts often remain asymptomatic for long periods $[9,10]$. The standard method for detecting renal involvement in patients with VHL is abdominal CT with contrast injection [11].Treatment of VHL disease depends on the location, size of the tumor, and associated cyst. [12] currently, there are no definitive guidelines regarding the surgical timing approach for these multiple, bilateral tumors. However, the primary goal of treatment should be carcinological control, rather than cure, as well as preservation of functional parenchyma to avoid morbidity associated with renal or adrenal loss. A series of studies have reported that the majority of CRCCs in VHL have low pathological content [13], progressive growth [14] and do not metastasize to a diameter of $3 \mathrm{~cm}<$ [15]. Therefore, an isolated renal lesion can be maintained under regular surveillance until it reaches $3 \mathrm{~cm}$ in diameter [16].

Several authors have shown a correlation between increasing tumor size and the risk of metastasis in VHL, leading to a general recommendation to use a diameter of $3.0 \mathrm{~cm}$ for surgical resection $[17,18,19$ -
20].This strategy results in a recurrence-free survival rate of $76 \%$ at 5 years and $20 \%$ at 8 years [19].

In contrast, the study by Neumann et al [21] did not detect metastatic spread below a size of $7 \mathrm{~cm}$ in diameter. A literature review focusing on tumor diameter revealed that cases with metastasis are almost

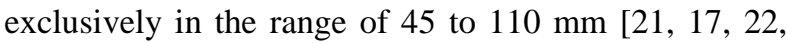
23]. These conflicting data may indicate that the development of metastasis in VHL disease-associated CRCC is different from that of sporadic CRCC.

Partial nephrectomy and enucleation have evolved as effective alternatives to radical nephrectomy. [24]. Because CRCC lesions are often small and multiple enucleation may also be justified in order to preserve the renal parenchyma, Intraoperatively, co-existing cysts should be aspirated to facilitate subsequent follow-up. [25] Laparoscopic partial nephrectomy appears to be similar to open partial nephrectomy in carcinology. [26] Percutaneous radiofrequency thermoablation PRFA will be a promising treatment for patients who cannot undergo surgical procedures, not only for carcinological purposes, but also preservation of renal function, as much as possible. PRFA can cause thermal injury to neighboring organs such as the intestine that are $5 \mathrm{~mm}$ from the CRCC [27]. Radiofrequency ablation may be indicated for small renal tumors $<4 \mathrm{~cm}$, especially in metastatic CRCC. [28] Tyrosine kinase inhibitors such as Sunitinib and Pazopanib directed against VEGF and other pro-angiogenic pathways are an approved treatment for metastatic CRCC [29,30]. These promising results led to the opening of a pilot trial of Pazopanib in VHL patients with measurable lesions, which is actively underway [31].

Half-dose sorafenib is comparable to sunitinib in oncologic outcome and long-term stability, with relatively few complications. [32] Sunitinib has acquired an important role in the treatment of sporadic metastatic renal cell carcinoma. Several studies and clinical cases suggest that sunitinib may be effective in patients with metastatic renal cell carcinoma in VHL disease [33].

\section{CONCLUSION}

The management of patients with VHL disease requires a multidisciplinary approach that includes a genetic counselor, neurosurgeon, medical oncologist, urologic surgeon, and ophthalmologist in addition to robust psychosocial support and strict lifestyle for patients and their families. Treatment should be as conservative as possible. Anti-angiogenic therapy represents the most recent development in the management of CRCC in VHL disease

\section{REFERENCES}

1. Lonser RR, Glenn GM, Walther M, Chew EY, Libutti SK, Linehan WM, Oldfield EH. von 
Hippel-Lindau disease. The Lancet. 2003 Jun 14; 361 (9374):2059-67.

2. Richard S, David P, Marsot-Dupuch K, Giraud S, Béroud C, Resche F. Central nervous system hemangioblastomas, endolymphatic sac tumors, and von Hippel-Lindau disease. Neurosurgical review. 2000 Apr 23 (1):1-22.

3. Bratt $\mathrm{O}$, Damber JE, Emanuelsson $\mathrm{M}$, Kristoffersson U, Lundgren R, Olsson H, Grönberg $\mathrm{H}$. Risk perception, screening practice and interest in genetic testing among unaffected men in families with hereditary prostate cancer. European Journal of Cancer. 2000 Jan 1; 36(2):235-41.

4. Zhang L, Xu B, Chen S, Lu K, Liu C, Wang Y, Zhao Y, Zhang X, Liu D, Chen M. The complex roles of microRNAs in the metastasis of renal cell carcinoma. Journal of nanoscience and nanotechnology. 2013 May 1; 13 (5):3195-203.

5. Bradley S, Dumas N, Ludman M, Wood L. Hereditary renal cell carcinoma associated with von Hippel-Lindau disease: a description of a Nova Scotia cohort. Canadian Urological Association Journal. 2009 Feb; 3 (1):32.

6. Malek RS, Omess PJ, Benson Jr RC, Zincke H. Renal cell carcinoma in von Hippel-Lindau syndrome. The American journal of medicine. 1987 Feb $1 ; 82(2): 236-8$.

7. Choyke PL, Glenn GM, Walther MM, Zbar B, Weiss GH, Alexander RB, Hayes WS, Long JP, Thakore KN, Linehan WM. The natural history of renal lesions in von Hippel-Lindau disease: a serial CT study in 28 patients. AJR. American journal of roentgenology. 1992 Dec;159 (6):1229-34.

8. Choyke PL, Glenn GM, Walther MM, Patronas NJ, Linehan WM, Zbar B. von Hippel-Lindau disease: genetic, clinical, and imaging features. Radiology. 1995 Mar;194 (3):629-42.

9. Schips L, Lipsky K, Zigeuner R, Salfellner M, Winkler S, Langner C, Rehak P, Pummer K, Hubmer G. Impact of tumor-associated symptoms on the prognosis of patients with renal cell carcinoma: a single-center experience of 683 patients. Urology. 2003 Dec 1; 62 (6):1024-8.

10. Valdés YA. Correlation between symptoms and survival in patients with renal cell carcinoma. Arch. Esp. Urol. 2009 Apr; 62 (3):201-6.

11. Lonser RR, Glenn GM, Walther M, Chew EY, Libutti SK, Linehan WM, Oldfield EH. Von Hippel-Lindau disease. The Lancet. 2003 Jun 14; 361 (9374):2059-67.

12. Von Hippel-Lindau Family Alliance Website (Information for Families, Clinicians, Researchers) Available from: http://www.vhl.org. [Last accessed on 2015 May 05].

13. Steinbach F, Novick AC, Zincke H, Miller DP, Williams RD, Lund G, Skinner DG, Esrig D, Richie JP, DeKernion JB, Marshall F. Treatment of renal cell carcinoma in von Hippel-Lindau disease: a multicenter study. The Journal of urology. 1995 Jun; 153 (6):1812-6.
14. NEUMANN HP, BENDER BU, BERGER DP, LAUBENBERGER J, SCHULTZE-SEEMANN WO, WETTERAUER U, FERSTL FJ, HERBST EW, SCHWARZKOPF G, HES FJ, JM CL. Prevalence, morphology and biology of renal cell carcinoma in von Hippel-Lindau disease compared to sporadic renal cell carcinoma. The Journal of urology. 1998 Oct 1 ; 160(4):1248-54.

15. Duffey BG, Choyke PL, Glenn G, Grubb RL, Venzon D, Linehan WM, Walther MM. The relationship between renal tumor size and metastases in patients with von Hippel-Lindau disease. The Journal of urology. 2004 Jul; 172 (1):63-5.

16. Herring JC, Enquist EG, CHERNOFF A, LINEHAN WM, CHOYKE PL, WALTHER MM. Parenchymal sparing surgery in patients with hereditary renal cell carcinoma: 10-year experience. The Journal of urology. 2001 Mar; 165(3):777-81.

17. Herring JC, Enquist EG, CHERNOFF A, LINEHAN WM, CHOYKE PL, WALTHER MM. Parenchymal sparing surgery in patients with hereditary renal cell carcinoma: 10-year experience. The Journal of urology. 2001 Mar; 165(3):777-81.

18. Joly D, Méjean A, Corréas JM, Timsit MO, Verkarre V, Deveaux S, Landais P, Grünfeld JP, Richard S. Progress in nephron sparing therapy for renal cell carcinoma and von Hippel-Lindau disease. The Journal of urology. 2011 Jun;185(6):2056-60.

19. Roupret M, Hopirtean V, Mejean A, Thiounn N, Dufour B, Chretien Y. Nephron sparing surgery for renal cell carcinoma and von Hippel-Lindau's disease: a single center experience. The Journal of urology. 2003 Nov; 170 (5):1752-5.

20. Matin, S. F., Ahrar, K., Wood, C. G., Daniels, M., \& Jonasch, E. (2008). Patterns of intervention for renal lesions in von Hippel- Lindau disease. BJU international, 102(8), 940-945.

21. NEUMANN HP, BENDER BU, BERGER DP, LAUBENBERGER J, SCHULTZE-SEEMANN WO, WETTERAUER U, FERSTL FJ, HERBST EW, SCHWARZKOPF G, HES FJ, JM CL. Prevalence, morphology and biology of renal cell carcinoma in von Hippel-Lindau disease compared to sporadic renal cell carcinoma. The Journal of urology. 1998 Oct 1; 160 (4):1248-54.

22. Ploussard G, Droupy S, Ferlicot S, Ples R, Rocher L, Richard S, Benoit G. Local recurrence after nephron-sparing surgery in von Hippel-Lindau disease. Urology. 2007 Sep 1; 70 (3):435-9.

23. Gupta GN, Peterson J, Thakore KN, Pinto PA, Linehan WM, Bratslavsky G. Oncological outcomes of partial nephrectomy for multifocal renal cell carcinoma greater than $4 \mathrm{~cm}$. The Journal of urology. $2010 \mathrm{Jul} ; 184(1): 59-63$.

24. Vroonhoven V, van Amstel P. Management of renal cell carcinoma in von Hippel-Lindau disease. 
European journal of clinical investigation. 1999 Jan;29 (1):68-75.

25. Nanri M, Uda M, Iguchi $Y$, Gouya N, Toma $H$, Kihara T. A case of renal cell carcinoma associated with von Hippel-Lindau disease and the necessity for family genetic diagnosis. Hinyokika kiyo. Acta urologica Japonica. 1999 Nov 1; 45 (11):755-8.

26. Ljungberg B, Cowan NC, Hanbury DC, Hora M, Kuczyk MA, Merseburger AS, Patard JJ, Mulders PF, Sinescu IC. EAU guidelines on renal cell carcinoma: the 2010 update. European urology. 2010 Sep 1;58(3):398-406.

27. Rhim H, Dodd III GD, Chintapalli KN, Wood BJ, Dupuy DE, Hvizda JL, Sewell PE, Goldberg SN. Radiofrequency thermal ablation of abdominal tumors: lessons learned from complications. Radiographics. 2004 Jan;24 (1):41-52.

28. Tsimafeyeu I, Zart JS, Chung B. Cytoreductive radiofrequency ablation in patients with metastatic renal cell carcinoma (RCC) with small primary tumours treated with sunitinib or interferon- $\alpha$. BJU international. 2013 Jul; 112(1):32-8.

29. Clinical Trials Database: NCT02108002. https://clinicaltrials.gov

30. Clinical Trials Database: NCT01436227. https://clinicaltrials.gov

31. Clinical Trials Database: NCT01436227. https://clinicaltrials.gov

32. Choi KH, Yu YD, Kang MH, Park DS. Sorafenib treatment for recurrent stage T1 bilateral renal cell carcinoma in patients with Von Hippel-Lindau disease: A case report and literature review. Canadian Urological Association Journal. 2015 Sep;9(9-10):E651

33. Jonasch E, McCutcheon IE, Waguespack SG, Wen S, Davis DW, Smith LA, Tannir NM, Gombos DS, Fuller GN, Matin SF. Pilot trial of sunitinib therapy in patients with von Hippel-Lindau disease. Annals of oncology. 2011 Dec 1; 22(12):2661-6. 